九州大学学術情報リポジトリ

Kyushu University Institutional Repository

\title{
NOTES ON THE AFRICAN SPECIES OF TETRAGNATHA (ARANEAE : TETRAGNATHIDAE)
}

Okuma, Chiyoko

https://doi.org/10.5109/2454

出版情報: ESAKIA. 22，pp.87-93，1984-11-20. Entomological Laboratory，Faculty of Agriculture， Kyushu University

バージョン :

権利関係 : 


\title{
NOTES ON THE AFRICAN SPECIES OF TETRAGNATHA (ARANEAE : TETRAGNATHIDAE)*
}

\author{
Сніуоко Окима \\ Entomological Laboratory, Faculty of Agriculture, \\ Kyushu University, Fukuoka 812, Japan
}

\begin{abstract}
Four species of the spider genus Tetragnatha, T. jaculator. T. javana, T. latro and T. tullgreni are redescribed and illustrated based on the African specimens. T.javana is recorded from Africa for the first time.
\end{abstract}

The genus Tetragnatha Latreille, 1804 has been represented by 48 species in the Afrotropical region (Roewer, 1942 ; Brignoli, 1983). The African spiders of the genus, unfortunately, have been poorly studied. In the present paper the redescriptions of four known species of Tetragnatha are given, which were collected from Côte d'Ivoire, Tanzania and Zaire. The importanceof the relative lengths of legs for the characteristics of species is also emphasized in this paper.

Before going further, I wish to express my hearty thanks to Prof. Y. Hirashima of Kyushu University for the helpful suggestions and encouragement throughout the course of this work. My hearty thanks are due to Dr. Paul Cochereau, Dr. H. Kunimi and Dr. H. Ono for their kindness in offering me the important specimens for the present study.

Tetragnatha jaculator Tullgren, 1910

Tetragnatha jaculator Tullgren, 1910, Aran. in:Sjöstedt Kilimand. Exped., 3 :150; Lawrence, 1936, Ann. Transv. Mus., 17(2): 152.

Specimen examined : 10, Côte d'Ivoire, Bouaké, VII. 1977, Los Sun Ly leg.

Distribution: Africa.

Male : The anterior and posterior rows of eyes are widely separated, the anterolateral eye somewhat produced. The conductor and embolus are finely attenuated at their tips. The abdomen is moderately slender, not continued posteriorly to spinnerets. The specimen well agrees with Tullgren's description and figures. Body length 6.8 mm ; carapacial length $2.1 \mathrm{~mm}$; abdominal length $4.7 \mathrm{~mm}$; cheliceral length $1.4 \mathrm{~mm}$.

* Contribution from the Entomological Laboratory, Faculty of Agriculture, Kyushu University, Fukuoka (Ser. 3, No. 157). 


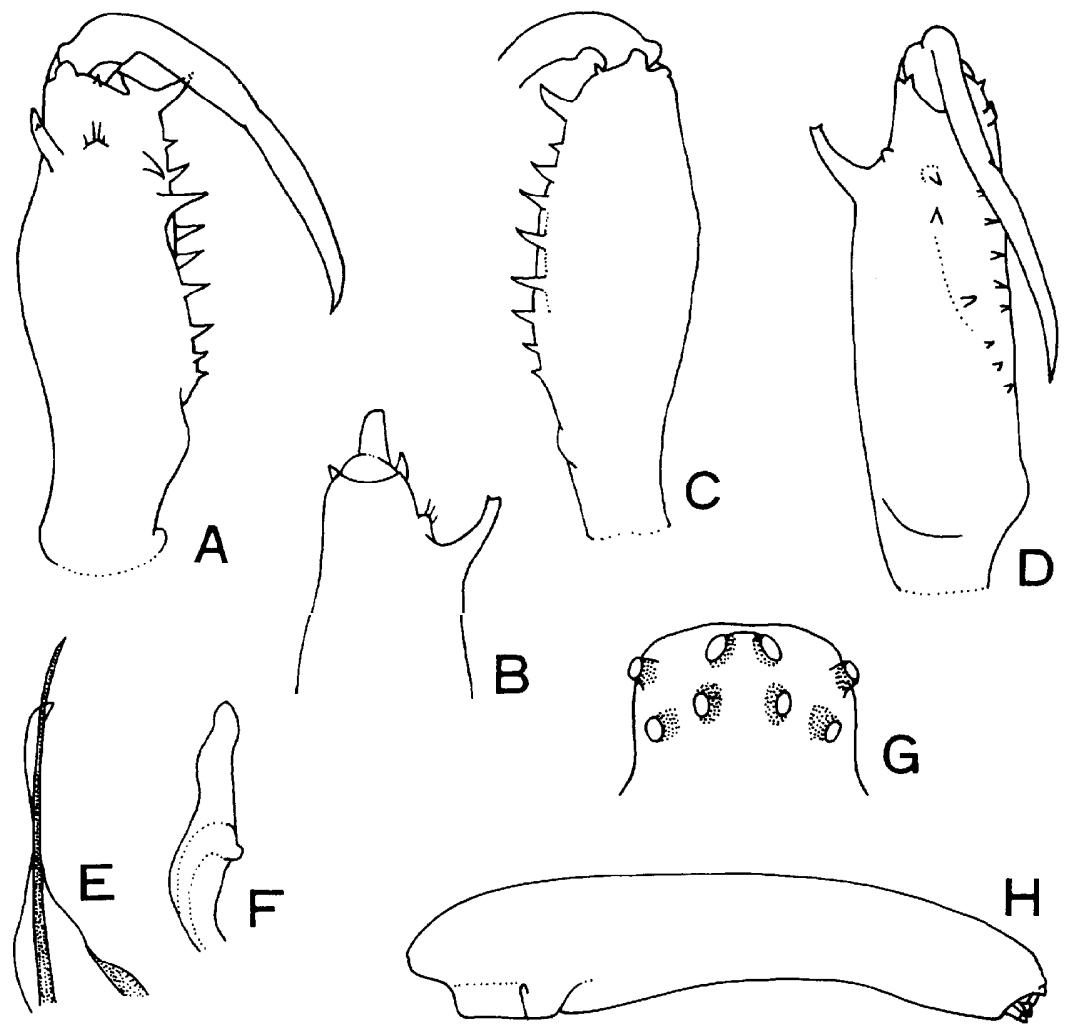

Fig. 1. Tetragnatha jaculator Tullgren. A : Left chelicera of male, dorsal view. B : Ditto, lateral view. C : Ditto, ventral view. D : Ditto, inner view. E: Distal portion of conductor and embolus of male. F: Paracymbium of male. G : Eye group of male. H : Abdomen of male.

Tetragnatha javana (Thorell, 1890)

Eucta javana Thorell, 1890, Ann. Mus. Civ. Genova, 28 : 236 ; Thorell,1895, Spiders of Burma, London,

P. 146 ; Simon, 1909, Bull. Sci. France Belg., 42 : 102 ; Gravely, 1921, Rec. Ind. Mus., Calcutta, 22 : 447 ; Saito, 1933, Trans. Sapporo Nat. Hist. Soc., 13(1): 47.

Tetragnatha (Eucta) javana: Okuma, 1968, Mushi, 42 : 100 ; Okuma, 1970, Mushi, 44 : 73.

SPecimens eXAmined : $60^{\circ} 0^{\prime}$ and $2 q q$, Tanzania, Bukoba, 25, VI. 1975, H. Kunimi leg ; $4 \sigma^{\prime} \sigma^{\prime \prime}$ and 11 q $q$, Côte d'Ivoire, Bouaké, VII. 1977, Los Sun Ly leg.

Distribution : Africa (new record) and S. E. Asia to New Guinea.

The female chelicerae are provided with a small tubercle on the outer side near the apex (Fig. 2J), but the tubercle is variable in the size and the shape (from only a small mark to a denticular cusp) in both specimens from Africa and S. E. Asia. Body length : male 8.3 to $11.8 \mathrm{~mm}$, female 13.0 to $17.0 \mathrm{~mm}$; carapacial length : male 2.2 to $2.6 \mathrm{~mm}$, female 2.7 to $3.0 \mathrm{~mm}$; abdominal length : male 6.2 to $9.3 \mathrm{~mm}$, female 11.0 to $14.0 \mathrm{~mm}$; cheliceral length : male 1.3 to $1.6 \mathrm{~mm}$, female 1.4 to $\mathbf{1 . 6} \mathrm{mm}$. 


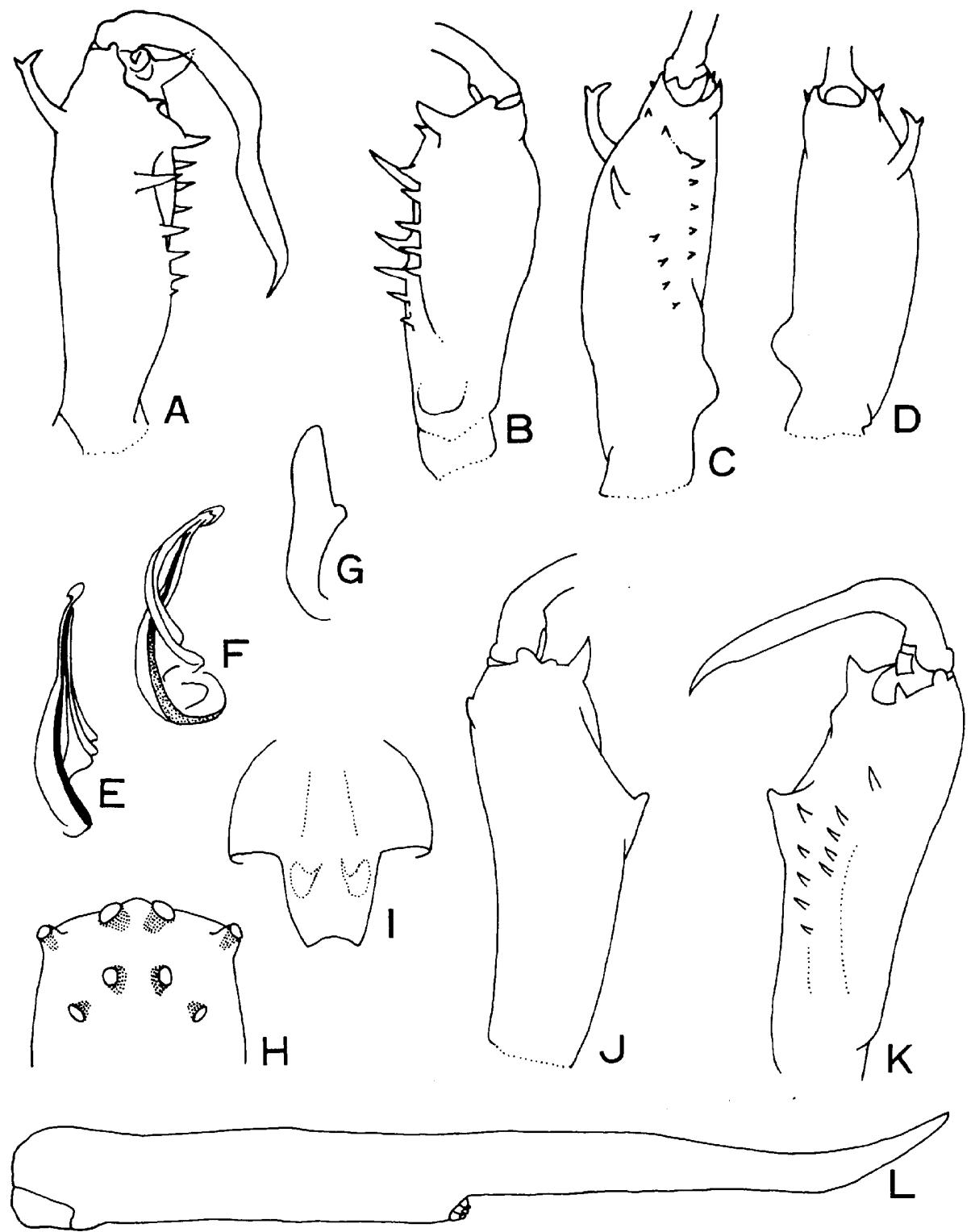

Fig. 2. Tetragnatha javana (Thorell). A : Left chelicera of male. B : Ditto, ventral view. C: Ditto, inner view. D: Ditto, lateral view. E and F: Distal portion of conductor and embolus of male. $\mathrm{G}$ : Paracymbium of male. $\mathrm{H}$ : Eye group of female. I : Genital fold of female. J : Left chelicera of female. $\mathrm{K}$ : Ditto, inner view. L : Abdomen of female.

Note :Tetragnatha javana (Thorell,1890) is very similar to T. isidis (Simon, 1880) from Egypt on account of the long caudal end of the abdomen in either sex and the stout tubercle near the middle of the upper and inner sides of the basal joint of the 


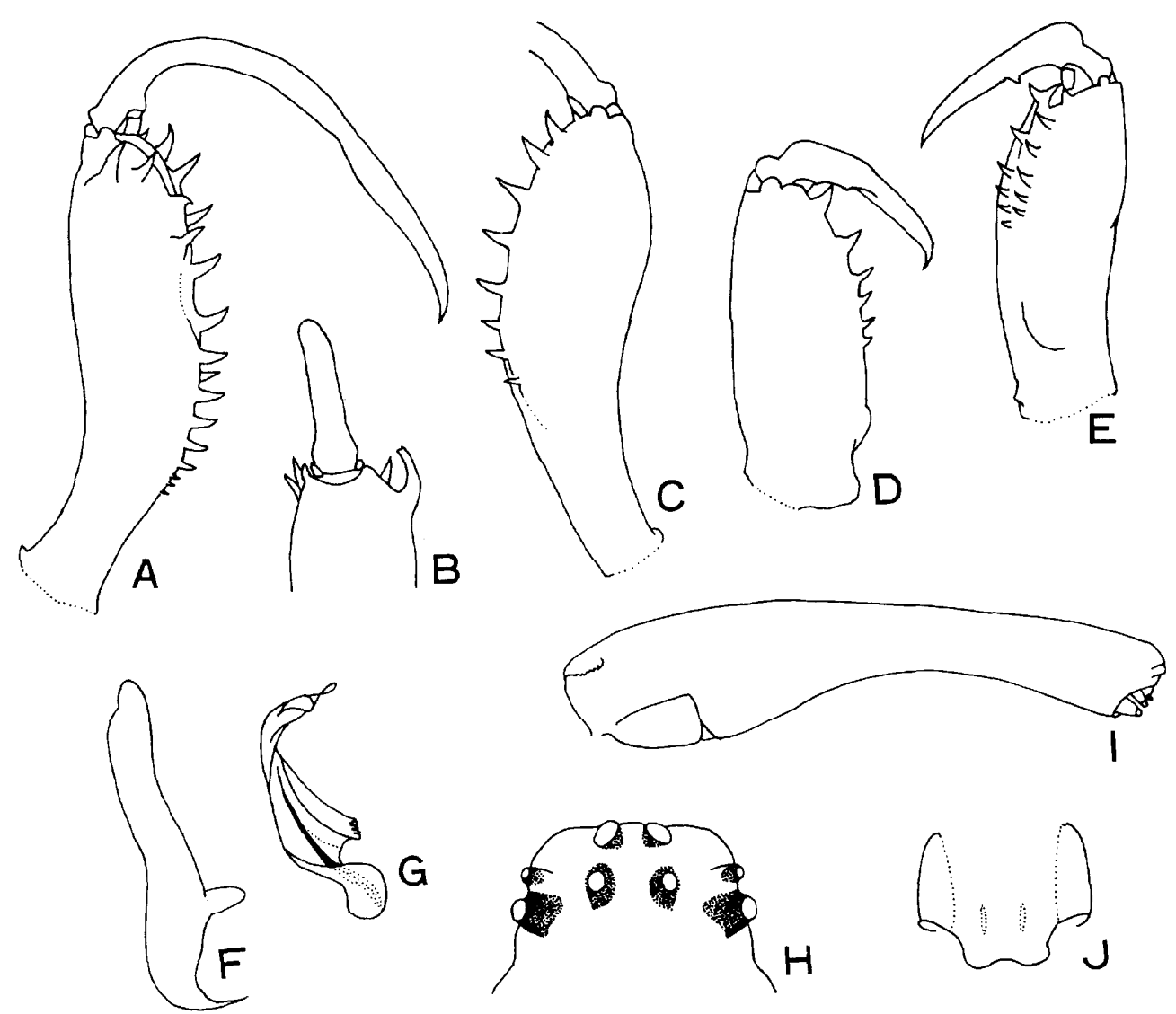

Fig. 3. Tetragnatha latro Tullgren. A : Left chelicera of male. B : Ditto, lateral view. C : Ditto, ventral view. D : Left chelicera of female. E : Ditto, inner view. F : Paracymbium of male. G : Distal portion of conductor and embolus of male. $\mathrm{H}$ : Eye group of male $\mathrm{I}$ : Abdomen of male. $\mathrm{J}$ : Genital fold of female.

female chelicer ae. Although the latter feature is not mentioned in the original description of isidis, it is referred to Lessert's (1915) redescription and figures. It is very probable that T.javana is a synonym of T.isidis, although Simon (1909) states that the former is distinct.

The African specimens before me very well agree in all details with the Asian specimens of $T$. javana. Since I have not seen the authentic specimens of $T$.isidis, the African species is treated as $T$. javana in this paper. Further studies of the African $T$.isidis are expected.

Tetragnatha latro Tullgren, 1910

Tetragnatha latro Tullgren, 1910, Aran. in : Sjöstedt Kilimand. Exped., $3: 148$.

Specimens examined : $6 \sigma^{\prime} \sigma^{\prime}$ and $2 q q$, Tanzania, Bukoba, 25. VI. 1975, H.Kunimi leg. 

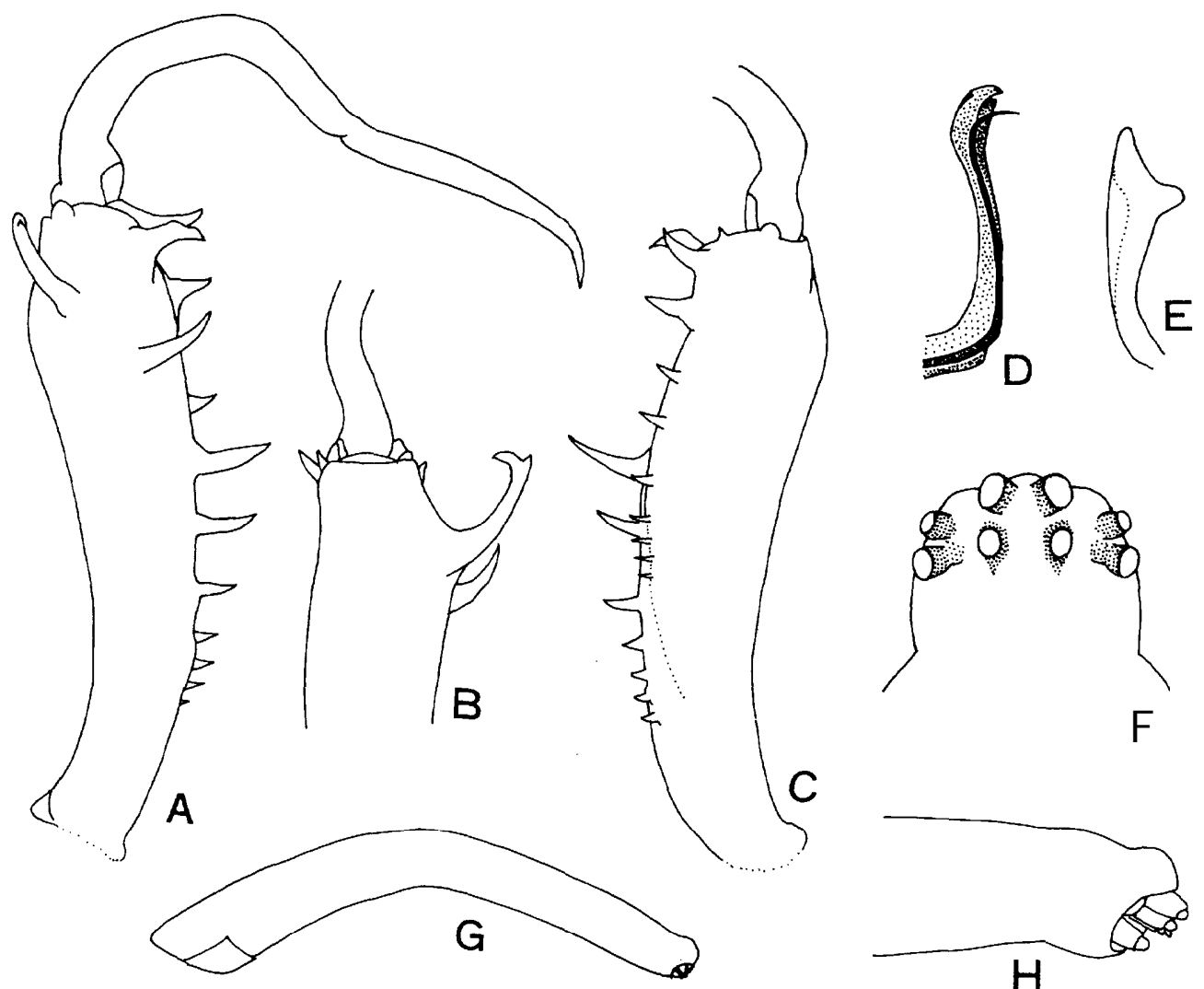

Fig. 4. Tetragnatha tullgreni Lessert. A.: Left chelicera of male. B : Ditto, lateral view. C: Ditto, ventral view. D : Distal portion of conductor and embolus of male. E : Paracymbium of male. F : Eye group of male. G : Abdomen of male. H : Distal portion of abdomen of male.

\section{DisTRIBUTION : Africa.}

The arrangement of eyes of this species somewhat resembles that of $T$.ceylonica from S.E. Asia. The chelicerae of the female are comparatively short, with a small cusp on the inner margin about one-third from the base in the fang (Fig. 3E). The abdomen is moderately slender and not continued posteriorly to spinnerets. Body length : male 6.4 to $9.0 \mathrm{~mm}$, female 6.7 to $7.3 \mathrm{~mm}$; carapacial length : male 2.2 to 2.9 $\mathrm{mm}$, female $2.2 \mathrm{~mm}$; abdominal length : male 4.2 to $6.2 \mathrm{~mm}$, female 4.5 to $5.4 \mathrm{~mm}$; cheliceral length : male 1.8 to $2.4 \mathrm{~mm}$, female $1.1 \mathrm{~mm}$.

Tetragnatha tullgreni Lessert, 1915

Tetragnatha tullgreni Lessert, 1915, Rev. Suisse 2001. 23(1): 18.

SPECIMEN EXAMINED : 1 ○', Zaire, Bokuma, Wald Ruki, Wurm-Longa, IX-X. 1977, J. Preuss leg. 
Table 1. Tetragnatha jaculator Tullgren : Relative lengths of total legs and femora.

\begin{tabular}{|c|c|c|c|c|c|c|c|c|}
\hline \multirow{2}{*}{\multicolumn{2}{|c|}{ Locality }} & \multicolumn{3}{|c|}{ 1st legs } & \multirow{2}{*}{$\begin{array}{c}\text { 1st legs } \\
\text { ratio }\end{array}$} & \multirow{2}{*}{$\begin{array}{c}\text { 2nd legs } \\
\text { ratio }\end{array}$} & \multirow{2}{*}{$\begin{array}{c}\text { 3rd legs } \\
\text { ratio }\end{array}$} & \multirow{2}{*}{$\begin{array}{c}4 \text { th legs } \\
\text { ratio }\end{array}$} \\
\hline & & 11 & mean \pm s.d. & range & & & & \\
\hline$\left(\operatorname{Legs}^{* *}\right)$ & $0^{x}$ & & & & & & & \\
\hline Bouaké & & 1 & 18.70 & & 100 & 67 & 30 & 63 \\
\hline (Femora) & $\sigma^{\pi}$ & & & & & & & \\
\hline Bouake & & 1 & 5. 50 & & " & 73 & 36 & 76 \\
\hline
\end{tabular}

$*$ The number of specimens. $\quad * *$ Femur + Patella + Tibia + Metatarsus + Tarsus.

Table 2. Tetragnatha javana (Thorell) : Relative lengths of total legs and femora.

\begin{tabular}{|c|c|c|c|c|c|c|c|c|}
\hline \multirow{2}{*}{\multicolumn{2}{|c|}{ Locality }} & \multirow{3}{*}{$\mathrm{n}$} & \multicolumn{2}{|c|}{ 1st legs } & \multirow{3}{*}{$\begin{array}{c}\text { 1st legs } \\
\text { ratio }\end{array}$} & \multirow{3}{*}{$\begin{array}{l}\text { 2nd legs } \\
\text { ratio }(r)\end{array}$} & \multirow{3}{*}{$\begin{array}{l}\text { 3rd legs } \\
\text { ratio }(\mathrm{Y})\end{array}$} & \multirow{2}{*}{$\begin{array}{l}\text { 4th legs } \\
\text { ratio (Y) }\end{array}$} \\
\hline & & & mean \pm s.d. & range & & & & \\
\hline$($ Legs $)$ & 8 & & & & & & & \\
\hline Tanzania & & 6 & $21.78 \pm 2.97$ & $18.10-24.60$ & 100 & $58 \quad(0.992)$ & $25 \quad(0.985)$ & $59(0.998)$ \\
\hline Bouake & & 4 & $27.26 \pm 1.06$ & $26.00 \quad-28.35$ & $\prime \prime$ & $54 \quad(0.987)$ & $23 \quad(0.979)$ & $55(0.988)$ \\
\hline Japan & & 10 & $24.63 \pm 2.29$ & $19.65-27.80$ & II & $57 \quad(0.969)$ & $25 \quad(0.918)$ & $58 \quad(0.959)$ \\
\hline Taiwan & & 3 & $20.07 \pm 1.75$ & $18.05-21.10$ & II & $56 \quad(0.993)$ & 24 (0. 992) & $56 \quad(0.998)$ \\
\hline Thailand & & 10 & $24.63 \pm 2.80$ & $19.90-30.10$ & II & $54(0.997)$ & 23 (0. 991) & $55(0.988)$ \\
\hline Tanzania & 우 & 2 & $24.43 \pm 0.13$ & $24.33-24.52$ & & 56 & 24 & 58 \\
\hline Bouake & & 11 & $25.97 \pm 2.77$ & $20.65-29.15$ & & $54 \quad(0.956)$ & 24 (0. 946) & $56 \quad(0.975)$ \\
\hline Japan & & 10 & $24.95 \pm 2.14$ & 20.75-27. 55 & & $55 \quad(0.943)$ & $25(0.863)$ & $57(0.941)$ \\
\hline Taiwan & & 1 & 23. 20 & & & 54 & 24 & 54 \\
\hline Thailand & & 10 & $26.07 \pm 1.77$ & $22.20-28.70$ & & $53(0.960)$ & $23(0.964)$ & $54(0.963)$ \\
\hline (Femora) & $\sigma^{7}$ & & & & & & & \\
\hline Tanzania & & 6 & 6. 23.0 .81 & $5.20-7.10$ & 100 & $64 \quad(0.991)$ & $31 \quad(0.994)$ & $72 \quad(0.993)$ \\
\hline Bouake & & 4 & $7.69 \pm 0.30$ & $7.30-7.95$ & " & $60 \quad(0.991)$ & 30 (0. 987) & $69(0.998)$ \\
\hline Japan & & 10 & $7.01 \pm 0.69$ & $5.55-7.90$ & " & $64 \quad(0.970)$ & $32(0.897)$ & 71 (0. 958) \\
\hline Taiwan & & 3 & $5.63 \pm 0.55$ & $5.00-5.90$ & $\prime \prime$ & $62(0.996)$ & $30(0.996)$ & $69(0.989)$ \\
\hline Thailand & & 10 & $6.90 \pm 0.68$ & $5.65-7.85$ & $\prime \prime$ & $61 \quad(0.990)$ & $30(0.968)$ & $67(0.924)$ \\
\hline Tanzania & 우 & 2 & $7.13 \pm 0.35$ & $7.10-7.15$ & & 62 & 31 & 72 \\
\hline Bouaké & & 11 & $7.62 \pm 0.76$ & 6. $10-8.50$ & & $60 \quad(0.959)$ & $30(0.981)$ & $70(0.970)$ \\
\hline Japan & & 10 & 7. $32 \pm 0.64$ & $6.00-8.10$ & & $61 \quad(0.958)$ & $31 \quad(0.894)$ & $70 \quad(0.925)$ \\
\hline Taiwan & & 1 & 6. 70 & & & 60 & 31 & 66 \\
\hline Thailand & & 10 & $7.57 \pm 0.51$ & $6.40-8.35$ & & $59(0.970)$ & $29(0.952)$ & $66(0.943)$ \\
\hline
\end{tabular}

Distribution : Africa.

Both abdomen and legs of the male of this species are very slender (Fig. 4G and Table 4). The abdomen is not continued posteriorly to spinnerets. The specimen well agrees with Lessert's description and figures except the body size (Lessert's specimen 
Table 3. Tetragnatha latro Tullgren: Relative lengths of total legs and femora.

\begin{tabular}{|c|c|c|c|c|c|c|c|c|}
\hline \multirow{2}{*}{ Locality } & \multirow[b]{3}{*}{$0^{7}$} & \multirow{2}{*}{$\mathrm{n}$} & \multicolumn{2}{|c|}{ 1st legs } & \multirow{3}{*}{$\begin{array}{l}\text { 1st legs } \\
\text { ratio }\end{array}$} & \multirow{2}{*}{$\begin{array}{l}\text { 2nd legs } \\
\text { ratio }(r)\end{array}$} & \multirow{3}{*}{$\begin{array}{l}\text { 3rd legs } \\
\text { ratio }(r)\end{array}$} & \multirow{3}{*}{$\begin{array}{l}\text { 4th legs } \\
\text { ratio }(Y)\end{array}$} \\
\hline & & & mean \pm s.d. & range & & & & \\
\hline (Legs) & & & & & & & & \\
\hline Tanzania & & 6 & $22.23 \pm 2.43$ & $18.45-24.63$ & 100 & $66(0.997)$ & $29(0.989)$ & 64 (0.997) \\
\hline Tanzania & 우 & 2 & $15.59 \pm 0.23$ & $15.42-15.75$ & "1 & 65 & 29 & 63 \\
\hline (Femora) & $0^{\pi}$ & & & & & & & \\
\hline Tanzania & & 6 & $6.25 \pm 0.69$ & $5.15-7.00$ & II & $73(0.995)$ & $36(0.973)$ & $76(0.992)$ \\
\hline Tanzania & . & 2 & $4.50 \pm 0.14$ & $4.40-4.60$ & II & 71 & 34 & 76 \\
\hline
\end{tabular}

Table 4. Tetragnatha tullgreni Lessert : Relative lengths of total legs and femora.

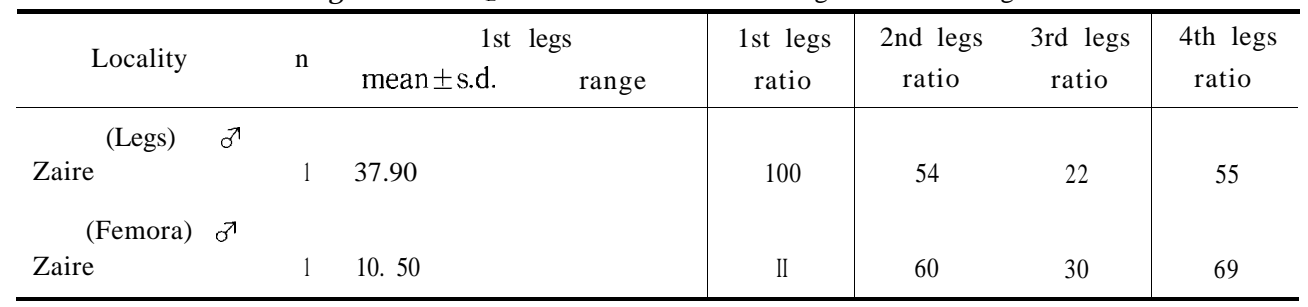

is smaller, body length $7.0 \mathrm{~mm}$; carapacial length $2.0 \mathrm{~mm}$; cheliceral length $1.7 \mathrm{~mm}$ ). Female is unknown. Body length $10.7 \mathrm{~mm}$; carapacial length $2.7 \mathrm{~mm}$; abdominal length $8.0 \mathrm{~mm}$; cheliceral length $2.2 \mathrm{~mm}$.

\section{$R$ eferences}

Brignoli, P. M., 1983. A catalogue of the Araneae described between 1940 and $1981.755 \mathrm{pp.}$ Manchester Univ. Press.

Chu, Y.-I. \& C. Okuma, 1970. Preliminary survey on the spider-fauna of the paddy field in Taiwan. Mushi, 44(9): 65-88.

Gravely, F. H., 1921. Some Indian spiders of the subfamily Tetragnathinae. Rec. Ind. Mus., $22: 423$ 459.

Lawrence, R. F., 1936. Spiders in : Scientific Results of the Vernay-Lang Kalahari-Expedition. Ann. Transv. Mus., 17(2): 145-158.

Lessert, R. de, 1915. Arachnides de l'Ouganda et de l'Afrique Orientale Allemanda. Rev. Suisse Zool., $23,(1): 1-89$.

Okuma, C., 1968. Preliminary survey on the spider-fauna of the paddy field in Thailand. Mushi, 42 (8) : 89-118.

Roewer, C. Fr., 1942. Katalog der Araneae I. 1040 pp. Bremen.

Saito, S., 1933. Notes on the spiders from Formosa. Trans. Sapporo Nat. Hist. Soc., 13 (1) : 32-61.

Simon, E., 1880. Description de trois nouvelles espèces d'arachnides de l'Egypt. Ann. Soc. Ent. France, 5 (10) : 98-99.

1909. Etudes sur les arachnides du Tonkin. Bull. Sci. France Belg., 42: 62-147.

Thorell, T., 1890. Studi sui Ragni Malesi e Papuani (I). Ann. Mus. Civ. Genova, 28: 1-419.

1895. Description Catalogue of the spiders of Burma. 406 pp. London.

Tullgren, A., 1910. Arachnoidea in :Sjöstedt, Y., Kilimandiaro-Meru Expedition (Stockholm), 3 : 85-172. 